\title{
Relationship of Self-efficacy and Teacher Knowledge for Prospective Elementary Education Teachers
}

\author{
Ann C. Sharp", Lorilynn Brandt, Elaine A. Tuft, Sandy Jay \\ School of Education, Utah Valley University, United States
}

Copyright $\bigcirc 2016$ by authors, all rights reserved. Authors agree that this article remains permanently open access under the terms of the Creative Commons Attribution License 4.0 International License

\begin{abstract}
This research investigates relationships between prospective teachers' self-efficacy of literacy instruction and their growing knowledge of literacy essentials. An instrument was used that is one part self-ratings of confidence levels in teaching specific literacy skills and one part assessment of literacy knowledge required to teach those skills. The survey was given three times over the course of 16-months to 70 prospective teachers. Results indicate that self-efficacy scores and knowledge scores significantly increase over time concurrently but without any predictive power of each other. Findings support Bandura's [1] self-efficacy theory.
\end{abstract}

Keywords Prospective Teacher Literacy Knowledge, Self-efficacy

\section{Introduction}

I can. I think I can. I cannot. Self-efficacy plays an acute role in how teachers think, feel, and behave, which in turn influences their students' achievements [2]. Additonally, the depth of a teacher's knowledge about literacy instruction also greatly influences student achievement [3]. Since there is a significant impact of both teachers' self-efficacy in teaching literacy and their depth of knowledge about literacy, a question surfaces as to how these two factors influence one another. The purpose of this study was to see if a relationship between prospective literacy teachers' sense of self-efficacy and their growing knowledge of literacy pedagogy existed.

\subsection{The Importance of Teacher Self-Efficacy}

Self-efficacy is defined as the belief in "one's ability to organize and execute an action required for a given attainment" [4, p.2]. Bandura [1] states that one's sense of efficacy is a powerful human characteristic which affects choices and efforts toward a task. Interestingly, self-efficacy is not based on one's actual ability to do a task, but rather on that person's perceived ability to complete that task. It also influences the choices individuals are willing to make, efforts extended to given tasks, and the amount of time that is willingly allotted to those tasks. Pajares [5] suggested that one tends to select tasks where there is a strong sense of competence. Thus, the level of self-efficacy may play a stronger role on choice of tasks and ability to accomplish them than does one's actual ability.

High self-efficacy can be a great advantage to classroom teachers. For the very reasons stated above, teachers with high self-efficacy are willing to spend more time, effort, and perseverance for the success of their students. Research has shown many positive outcomes for those teachers with a high sense of self-efficacy. For example, teachers with high self-efficacy tended to demonstrate competence and appear more organized [6], be more willing to try new methods [7], show greater enthusiasm for teaching [8], and engage their students more [9]. All of these qualities would suggest a more successful teacher and classroom experience. Furthermore, these teachers seemed to demonstrate critical qualities for closing learning gaps, such as being more persistent in helping struggling students [10], attending more closely to the needs of low-performing students [11], and being less critical of students' mistakes [12].

Finally, prospective teachers with a high sense of self-efficacy seem to internalize the content of teacher education programs better [13-15]. This outcome is of particular interest to teacher education programs as it suggests the importance of helping to establish high self-efficacy for prospective teachers early in their preparation. Doing this may have a greater impact on future teachers than waiting until after they are already in their classrooms [16,17].

Self-efficacy, according to Bandura [1], is a consequence of four sources of personal information. One of those sources, in this case, is how well prospective teachers perceive their accomplishments to be when performing literacy instruction. If they see themselves as successful, it heightens their expectations of being successful in the future, thus having a direct bearing on their choices to persist even if they have an occasional failing experience. 
These successful experiences are referred to as mastery experiences.

The second source of personal information is vicarious experiences. Vicarious experiences are understandings gained when observing qualified others as they successfully perform literacy instruction. Learning from others' modeling allows prospective teachers to translate their observations into their own instruction. This is best achieved when there are clear guidelines used to interpret the modeled behavior, thereby providing a rationale for future successful outcomes.

The third source of information that feeds self-efficacy is verbal persuasion, or feedback that is given by qualified others intended to enlighten the prospective teacher in his or her areas of strengths and weaknesses. Verbal persuasion can also includen prospective teachers' own reflections on their learning and their instructional performances.

The fourth source of information comes from the psychological state of the prospective teacher. The teacher's emotional state (i.e. stress, relaxed, overwhelmed, in control) will have informative significance on personal competence. Anxiety and fear can debilitate the outcomes of any instructional performance causing one to believe prematurely that they are not good at the instruction. On the other hand, one who feels more relaxed and in control will take in stride mistakes made and come away with a sense of being capable.

These four sources of information, personal performance, vicarious experiences, verbal persuasion, and psychological state, enhance or deter teacher self-efficacy. These sources will affect how perspective teachers acquire and hone their instructional skills in literacy throughout the education program and beyond in their own classroom [2].

\subsection{Importance of Teacher Knowledge}

Teacher knowledge, like self-efficacy, also affects teachers' success. In fact, one of the strongest influences on student reading success is teacher knowledge of research based principles and effective application of them [3,18]. The linkage of teacher knowledge to effectiveness of instruction for students has been confirmed for decades. For instance, in the landmark report Becoming a Nation of Readers: A Report of the Commission of Reading, it is stated that teacher knowledge and performance account for 15 percent of the variation among children in reading achievement [19]. Of all the factors considered as possible contributors of student success, teacher knowledge made the biggest difference in student scores.

Additionally, in an extensive national study done by Ferguson [20], results showed that money spent on training more highly qualified teachers resulted in greater improvement of student achievement scores than any other use of school money or resources. The schools that produce high student reading and writing achievement test scores are ones that have teachers who are knowledgeable and can articulate the purposes of their work. This finding is true regardless of socioeconomic status or commercial reading programs provided by the school for instruction [21,22]. That is, students' academic growth is affected more by a knowledgeable teacher's instruction than any other single factor, including families, neighborhoods, and the schools students attend $[23,24]$.

The understanding that teacher knowledge is hugely important in student achievement can guide work with prospective teachers. If teacher education programs are vigilant in helping students to grasp the necessary, research-based concepts for reading instruction, those students are able to go forth in the classrooms using and implementing this knowledge to help young readers be successful. This then would aid in closing the learning gap between those who successfully read and those who struggle.

With both self-efficacy and teacher knowledge clearly manifesting as contributing factors to teacher success, we explored the answers to three questions:

- Does self-efficacy change over time as knowledge constructs build?

- Does prospective teacher knowledge predict self-efficacy?

- Does prospective teachers' self-efficacy predict their literacy knowledge?

\section{Methods}

\subsection{Participants and Setting}

The participants in this study were 70 prospective elementary school teachers enrolled in a teacher preparation program at a large teaching university in the western United States. They included 4 males and 66 females with a high rate being nontraditional students. During the study, students were enrolled in two different literacy methods courses. Literacy Methods I took place during the last semester of the students' junior year. The topics for that class were oral language, early literacy, phonics, and assessment. Literacy Methods II took place in the first semester of the students' senior year. The topics of this course were fluency, vocabulary instruction, comprehension, and content area reading. The final semester of the students' senior year, they participated in a student teaching experience.

Both semesters of literacy methods courses included a three-week practicum where prospective teachers were given specific assignments to perform literacy methodology in an elementary classroom. These assignments included such things as teaching guided reading with a small group of elementary-age students as well as teaching comprehension strategy lessons to a whole class. Students' assignments included using preplanned and well-structured lesson plans.

Typical literacy assignments required personal reflection on what was learned, asking for insights and clarifying 
moments. Assignments often required practicing the instructional technique or literacy assessment on an early literacy learner. Academic readings and lectures were accompanied with group work, discussions, modeling by the literacy professor of various literacy instructional methods, and assessments intended to judge prospective teachers' grasp of the course content. These activities were grounded on reading research and best practices.

The student teaching experience was designed to provide prospective teachers with a skilled cooperating teacher who modeled instruction at first and then gradually turned the classroom over to the prospective teacher. Cooperating teachers typically familiarize the student teacher to the classroom with one to two weeks of orientation, allowing observations of instructional modeling while giving minimal duties like teaching one-on-one and working with small groups. Cooperating teachers leave the classroom for the last six weeks of an eleven-week period, monitoring the classroom only occasionally. During student teaching the prospective teacher will receive verbal and written feedback as to their strengths and weaknesses by both the cooperating teacher and a field advisor assigned to administer performance evaluations.

\subsection{Instrument and Procedure}

The prospective teachers were given an instrument that was part attitudinal survey and part content knowledge exam. The first part consisted of 10 Likert-type Scale items where the students rated themselves from 0 to 100 (even 10 's) on their perceived ability to teach literacy. The items were constructed to fit Bandura's [25] suggestions. They were also suited for a specific domain of literacy instruction to avoid vagueness and uncertainty [25]. The students rated their ability to teach phonological awareness, comprehension strategies, vocabulary instruction, fluency, struggling readers, motivation, lesson planning, phonics, spelling, and assessment. Cronbach alpha coefficients were between .91 and .96 across the three administrations. Sample Likert-type Scale items include the following:

Rate your degree of confidence by circling a number from 0 (cannot do it at all) to 100 (highly certain can do).

- Teaching early reading skills such as concept of print, phonological awareness, and phonics.

- Teaching meaning related skills such as comprehension strategies and vocabulary

- Motivating nonreaders

The second part of the instrument consisted of 20 multiple-choice questions that measured teacher knowledge. These questions were based on the self-efficacy topics, assessing content knowledge related to those topics. They were partially taken from Teacher Knowledge of Reading by Eciprieto [26] and several were constructed separately. Examples of the knowledge questions include:

- How many phonemes are in the word straight?

- What are the five components necessary for learning to read as suggested by the National Reading Panel
(2000)?

- An effective way to increase reading speed is:

- Identify the item below that is an example of research-based multiple-strategy comprehension instruction:

- Round robin reading

- Chunking

- Choral reading

- Repeated readings

- Identify the item below that is an example of research-based multiple-strategy comprehension instruction:

- Visualization

- Close reading

- Scaffolding

- Assisted reading

The instrument was administered three times to the study participants over the course of three semesters (approximately 16 months with 11.5 months between the first and second administration and 4.5 between the second and third.). The first administration was given at the beginning of Literacy Methods I, the second at the end of Literacy Methods II, and the third after the completion of student teaching.

\subsection{Data Analysis}

To answer the study's questions of whether the prospective teachers' knowledge predicts their self-efficacy and whether the prospective teachers' self-efficacy can predict their literacy knowledge, bivariate regressions were done with the corresponding items from the survey part of the instrument with the knowledge part of the instrument in both directions. To inform the question of whether self-efficacy changes over time as knowledge of literacy constructs builds, a variety of $t$-tests were completed. Since we had the need to establish that knowledge of literacy constructs were building, and we were interested in whether and where significant change might occur, paired $t$-tests were done for the items on the knowledge part of the instrument comparing the first administration to the second, the second to the third, and the first to the third. Likewise, paired $t$-tests were then completed to compare the Likert Scale self-efficacy items from the first administration to the second, the second to the third, and the first to the third.

\section{Results}

The results from the data analyses described previously are reported in the following sections. Results are organized according to our three research questions:

- Does self-efficacy change over time as knowledge constructs build?

- Does prospective teacher knowledge predict self-efficacy?

- Does prospective teachers' self-efficacy predict their literacy knowledge? 
Table 1. Change in Self-efficacy Scores Over Time

\begin{tabular}{|c|c|c|c|c|c|c|}
\hline \multirow{2}{*}{ Self-Efficacy Category } & \multicolumn{3}{|c|}{ Means } & \multicolumn{3}{|c|}{$t$-test $p$-values } \\
\cline { 2 - 7 } & $\mathrm{M} 1$ & $\mathrm{M} 2$ & $\mathrm{M} 3$ & $1^{\text {st }}-2^{\text {nd }}$ & $1^{\text {st }}-3^{\text {rd }}$ & $2^{\text {nd }}-3^{\text {rd }}$ \\
\hline 1. Phonological Awareness & 71.29 & 85 & 88.57 & $3.56 \mathrm{E}-07^{*}$ & $1.9 \mathrm{E}-09^{*}$ & $0.016^{*}$ \\
\hline 2. Comprehension and Vocabulary & 64.29 & 89.71 & 92 & $1.05 \mathrm{E}-07^{*}$ & $7.59 \mathrm{E}-19^{*}$ & 0.07 \\
\hline 3. Fluency & 60.14 & 89.71 & 89.71 & $1.14 \mathrm{E}-21^{*}$ & $1.14 \mathrm{E}-21^{*}$ & 1 \\
\hline 4. Student Achievement & 71.57 & 85.71 & 88.29 & $2.33 \mathrm{E}-09^{*}$ & $9.66 \mathrm{E}-10^{*}$ & 0.06 \\
\hline 5. Struggling Readers & 62.71 & 81.14 & 83.57 & $3.99 \mathrm{E}-06^{*}$ & $1.2 \mathrm{E}-15^{*}$ & $0.02^{*}$ \\
\hline 6. Motivation & 70.86 & 84.14 & 83.57 & $3.99 \mathrm{E}-06^{*}$ & $3.46 \mathrm{E}-05^{*}$ & 0.76 \\
\hline 7. Scaffolding Instruction & 55.71 & 89.86 & 88.71 & $3.02 \mathrm{E}-18^{*}$ & $2.71 \mathrm{E}-18^{*}$ & 0.4 \\
\hline 8. Phonics and Spelling & 68 & 76 & 88.71 & $0.02^{*}$ & $3.16 \mathrm{E}-13^{*}$ & $0.0004^{*}$ \\
\hline 9. Assessment & 71.43 & 88.14 & 90.29 & $1.25 \mathrm{E}-08^{*}$ & $2.2 \mathrm{E}-10^{*}$ & 0.22 \\
\hline 10. Analyze Assessment for Instruction & 68.29 & 77.86 & 89.43 & $0.04^{*}$ & $1.31 \mathrm{E}-11^{*}$ & $0.002^{*}$ \\
\hline
\end{tabular}

*statistically significant $(p<.05)$

Table 2. Change in Percent of Students Who Answered Knowledge Questions Correctly Over Time

\begin{tabular}{|c|c|c|c|c|c|c|}
\hline \multirow{2}{*}{ Knowledge Question } & \multicolumn{3}{|c|}{ Means (in percents) } & \multicolumn{3}{|c|}{$t$-test $p$-values } \\
\hline & M1 & M2 & M3 & $1-2$ & $1-3$ & $2-3$ \\
\hline 11. How many phonemes are in the word 'straight'? & 27.14 & 32.86 & 44.29 & 0.37 & 0.022 & 0.14 \\
\hline $\begin{array}{l}\text { 12. Students who are struggling readers benefit from all the } \\
\text { following except: }\end{array}$ & 57.14 & 61.43 & 65.71 & 0.61 & 0.31 & 0.52 \\
\hline 13. An effective way to increase students' reading speed is: & 61.43 & 82.86 & 84.29 & $0.006^{*}$ & $0.0012 *$ & 0.78 \\
\hline $\begin{array}{l}\text { 14. Identify the item below that is an example of } \\
\text { research-based multiple-strategy comprehension instruction. }\end{array}$ & 71.43 & 57.14 & 68.57 & 0.058 & 0.70 & 0.10 \\
\hline $\begin{array}{l}\text { 15. The National Reading Panel named five essential skill } \\
\text { components necessary for learning to read .. }\end{array}$ & 7.14 & 40.0 & 75.71 & $5.41 \mathrm{E}-06^{*}$ & $5.22 \mathrm{E}-19^{*}$ & $1.4 \mathrm{E}-06^{*}$ \\
\hline $\begin{array}{l}\text { 16. According to research, which of the following is not one } \\
\text { of the ways that students learn meaning of words indirectly? }\end{array}$ & 31.43 & 55.71 & 48.57 & $0.002 *$ & $0.033^{*}$ & 0.30 \\
\hline $\begin{array}{l}\text { 17. The teacher has students review and practice previously } \\
\text { taught letter-sound correspondences. . . }\end{array}$ & 64.29 & 80.0 & 82.86 & $0.03 *$ & $0.008^{*}$ & 0.60 \\
\hline $\begin{array}{l}\text { 18. Which words from a story should a teacher identify to use } \\
\text { for vocabulary instruction? }\end{array}$ & 44.29 & 55.71 & 64.29 & 0.13 & $0.009 *$ & 0.26 \\
\hline $\begin{array}{l}\text { 19. Each student orally reads a grade level passage as the } \\
\text { teacher records word accuracy. Which student was reading at } \\
\text { his/her instructional level? }\end{array}$ & 57.14 & 75.71 & 82.86 & $0.02 *$ & $0.0007^{*}$ & 0.17 \\
\hline 20. A word that contains an open syllable is: & 54.29 & 71.43 & 78.71 & $0.03 *$ & $0.001 *$ & 0.25 \\
\hline $\begin{array}{l}\text { 21. Which of the following is not a component of Reciprocal } \\
\text { Teaching? }\end{array}$ & 61.43 & 92.86 & 90.0 & $1.4 \mathrm{E}-06^{*}$ & $0.0001^{*}$ & 0.53 \\
\hline $\begin{array}{l}\text { 22. Which of the following scenarios would best help } \\
\text { students build reading fluency? }\end{array}$ & 79.71 & 91.13 & 92.75 & 0.07 & $0.01 *$ & 0.7 \\
\hline 23. A test that is reliable is one that: & 52.86 & 57.14 & 51.43 & 0.58 & 0.86 & 0.35 \\
\hline $\begin{array}{l}\text { 24. Offering students the support they need to accomplish } \\
\text { tasks includes sequencing skills, ... }\end{array}$ & 47.14 & 65.71 & 75.14 & $0.02 *$ & $0.0008^{*}$ & 0.13 \\
\hline $\begin{array}{l}\text { 25. Being aware of one's own thinking processes during } \\
\text { reading, such as focusing one's attention. . }\end{array}$ & 85.71 & 85.71 & 81.43 & 1 & 0.44 & 0.26 \\
\hline $\begin{array}{c}\text { 26. The majority of children who struggle when learning to } \\
\text { read: }\end{array}$ & 45.71 & 60.0 & 42.86 & 0.13 & 0.74 & 0.03 \\
\hline $\begin{array}{l}\text { 27. Which of the following sentences does not apply to } \\
\text { graphic organizers? }\end{array}$ & 52.86 & 88.57 & 75.71 & $1.56 \mathrm{E}-07 *$ & $0.004 *$ & $0.04 *$ \\
\hline 28. Which sound is the onset of big? & 88.57 & 90.0 & 95.65 & 0.74 & 0.13 & 0.10 \\
\hline 29. Identify the definition of a morpheme: & 54.29 & 57.14 & 65.71 & 0.73 & 0.20 & 0.13 \\
\hline $\begin{array}{l}\text { 30. During a phonemic awareness lesson, the teacher says } \\
\text { "/m/ /a/ /p/." Then the students say, "map." The students are: }\end{array}$ & 71.43 & 72.86 & 71.43 & 0.85 & 1 & 0.81 \\
\hline
\end{tabular}

*statistically significant $(p<.05)$ 


\subsection{Self-Efficacy Ratings Over Time}

The participating prospective elementary teachers' self-efficacy ratings started relatively high even before the literacy methods courses began. Still, self-efficacy changed significantly over time. Confidence increased significantly between the beginning of Literacy Methods I and the ending of Literacy Methods II and also between the beginning of Literacy Methods I and the end of student teaching on all topics. Confidence increased significantly between the ending of Literacy Methods II and the end of student teaching on four topics: phonological awareness, phonics and spelling, struggling readers, and analysis of assessments (see Table 1).

\subsection{Knowledge over Time}

For many of the knowledge items, the percent of participating students who got the item correct changed significantly over time. Most often the increase was between the first and second administration (beginning and ending of literacy methods courses) with an even greater increase between the first and third administration (beginning of literacy courses and end of student teaching). Often, there was an improvement between the second and third administration, but because the increase had been so great between the first and second administration, there wasn't room for the increase to be significant. Curiously, a couple of times, the difference on an item between the second and third administration was significant, but there was a decrease in the percentage of students who answered the question correctly. However, in general, there was a steady increase in the percentage who answered the questions correctly, although not always significant as can be seen in Table 2.

\subsection{Relationship Between Knowledge Base Scores and Teachers' Self-Efficacy Scores}

According to bivariate regressions, students' total score on the content knowledge items did not significantly predict the total score on the self-efficacy items (and vice versa) when comparing any of the combinations of when the instrument was administered. Likewise, when comparing self efficacy scores with content knowledge scores through Pearson product-moment correlation, the correlation coefficients showed little or no relationship each time the students completed the instrument $\left(1^{\text {st }}\right.$ time, $\rho=0.11 ; 2^{\text {nd }}$ time, $\rho=0.07 ; 3^{\text {rd }}$ time, $\left.\rho=0.07\right)$. When content knowledge items were matched with corresponding self-efficacy items, in most cases, confidence in an area of self-efficacy did not significantly predict whether they got the related content knowledge item correct - in both directions - any of the times the instrument was administered. However, there were a few exceptions for non-obvious reasons. These instances can be seen in Table 3 .
Table 3. Instances of Non-obvious Significant Bivariate Regression $(p<.05)$

\begin{tabular}{|c|c|c|c|}
\hline $\begin{array}{c}\text { Self-Efficacy } \\
\text { Category }\end{array}$ & $\begin{array}{c}\text { Knowledge Question } \\
\text { Stem }\end{array}$ & $\begin{array}{c}\text { Instrument } \\
\text { Administration }\end{array}$ & $\begin{array}{c}p \\
\text { value }\end{array}$ \\
\hline Fluency & $\begin{array}{c}\text { An effective way to } \\
\text { increase students } \\
\text { reading speed is: }\end{array}$ & $1^{\text {st }}$ & 0.05 \\
\hline $\begin{array}{c}\text { Scaffolding } \\
\text { Instruction }\end{array}$ & $\begin{array}{c}\text { Which the } \\
\text { following is not a } \\
\text { component of } \\
\text { Reciprocal Teaching? }\end{array}$ & $3^{\text {rd }}$ & 0.05 \\
\hline $\begin{array}{c}\text { Struggling } \\
\text { Readers }\end{array}$ & $\begin{array}{c}\text { struggling readers } \\
\text { benefit from all the } \\
\text { following except: }\end{array}$ & $3^{\text {rd }}$ & 0.015 \\
\hline
\end{tabular}

In summary, students' self-efficacy significantly increased over time. Concurrently, knowledge of literacy constructs generally increased over time, and in most cases the increase was significant. However, prospective teachers' knowledge did not predict self-efficacy, nor did prospective teachers' self-efficacy predict their literacy knowledge.

\section{Discussion}

The results of this study show prospective teachers' self-efficacy increasing in their ability to teach literacy. Although the prospective teachers' confidence began at an already high level, there was a significant increase between the initial start of their literacy methods courses to the conclusion of them. There was also an increase in confidence continuing during the student teaching experience. This is gratifying since in the past, self-efficacy has been shown to be a strong predictor in many facets of successful teaching [2].

Interestingly, self-efficacy significantly increased over all three testing periods in four of the ten categories. Although there was statistically significant increase in all categories of self-efficacy between the first and second administration and from the first to the third, only four showed significant difference from the second period (end of the Literacy Methods courses) to the third administration (end of student teaching). Those areas were phonological awareness, phonics, struggling readers, and analysis of assessments. These four areas are often novel concepts for prospective teachers having new vocabulary terms to learn and different instructional techniques to master. They can seem complex, cumbersome, or even overwhelming. The other six areas, which include such things as vocabulary, fluency, and comprehension, are more familiar literacy constructs, providing most prospective teachers with background knowledge before coming into the program.

The recognized challenge of the more complex constructs is met within the literacy methods courses with a great deal of emphasis in terms of class discussion, assignments, and practice. The exposure to real-time experiences such as encounters with struggling readers or actually teaching phonological awareness, phonics lessons, or analyzing assessments to plan instruction, may have allowed the 
impetus needed for further significant increase of self-efficacy in these four areas. According to Bandura [1], persistence in activities that seem difficult often lead to successful experiences. In turn, successful experiences along with opportunities for feedback enhance self-efficacy.

Although not always guaranteed, student teaching is designed to provide all four sources of personal information that Bandura [1] identified as contributing to self-efficacy. First, successful experiences of applying the instructional literacy techniques in the classroom of students is the best possible source for personal information. Successful experiences signal to the prospective teacher that she or he can expect further success. Second, vicarious experiences are provided as the prospective teacher observes the cooperating teacher model various instructional tasks. Vicarious experiences provide the prospective teacher with positive examples of how the instructional task can be successfully completed. Third, opportunities for feedback and reflection are operative when the cooperating teacher and the field supervisor prepare verbal and written evaluations of the prospective teacher's performance. Feedback and reflection give insights into the teaching performances that were well executed as well as constructive suggestions for improvement. Finally, the education program's methodical preparation of the perspective teacher and the cooperating teacher's thoughtful scaffolding of the student teaching experience enhance a positive psychological stance by promoting a smooth and enjoyable experience for the prospective teacher.

Bandura's [1] theory suggests that individuals with strong self-efficacy will most likely choose to not only cope with difficulties, but also put forth effort to overcome them. In this light, high self-efficacy from the beginning of the literacy methods courses might have acted in the favor of these prospective teachers allowing them to persevere through the confusion and complexity of the more difficult literacy constructs until they became more confident.

At the same time the prospective teachers' confidence was increasing, knowledge of literacy pedagogy also increased significantly throughout two semesters of literacy methods courses. The pre and post assessments showed that the prospective teachers grew in their knowledge of literacy instruction on topics such as assessment to instruction, struggling readers, pedagogy, phonemic awareness, phonics, fluency, vocabulary instruction, and comprehension strategies. This also is gratifying as the importance of their teacher knowledge will have a bearing on their future students' achievement [19]. These prospective teachers appear to be getting a firm foundation in literacy knowledge that will support them in their own classrooms.

However, no predictive power between teacher knowledge and self-efficacy was found. For these prospective teachers, whether they knew the literacy content knowledge or not, their self-efficacy was high. Although both knowledge and self-efficacy are strong factors in the future success of prospective teachers, the results of this study indicate that one is not dependent on the other.

Perhaps no predictive power was found because of the already high self-efficacy of the prospective teachers, starting at a higher relative level than their knowledge did. As noted, at the beginning of their educational program, many of these prospective teachers had more self-efficacy than warranted by their level of knowledge. Consistent with these findings, a study where preschool teachers were given a survey to determine their level of confidence in early literacy concepts found that the perceived confidence level of the preschool teachers was greater than their background and knowledge justified [27]. Likewise, it would appear that the prospective teachers in this study were already self-efficacious before they became knowledgeable. This finding supports Bandura's [1] theory on self-efficacy which suggest that self-efficacy is not reliant on actual knowledge, but is based on a perceived belief in one's ability to be successful.

\section{Limitations}

The analysis of student self-efficacy was constrained because of the sample size of the analysis as well as the limited population. Typically, larger sample sizes give better estimates of the population. This study was restricted to one university and just 70 students. Thus the results of this study may be limited to a select population that can be generalized to only our prospective teachers.

Another limitation of the study was it relied only on one source of data collection - the instrument that was part attitudinal and part content knowledge. We recognize that one instrument cannot comprehensively measure self-efficacy and knowledge. For instance, we recognize that the multiple-choice test used cannot show all that our prospective teachers had learned. Any one knowledge assessment is inadequate in measuring the full knowledge of any individual.

Despite these limitations, the current analysis has provided some insight into the relationship between the prospective teachers' knowledge and their self-efficacy. This study has shown that though self-efficacy and knowledge do not seem to predict one another, they can both be increased and strengthened concomitantly. It would also appear that strong self-efficacy in the beginning stages of obtaining literacy knowledge might influence prospective teacher's ability to successfully persevere even when the knowledge content seems daunting.

\section{Conclusions}

Researchers suggest that in order for beginning teachers to be successful in helping young readers, self-efficacy [2] and knowledge base [3] are vital. Both efficacy and knowledge are shaped through experiences prospective teachers have in their teacher education program. To build 
strong knowledge and high self-efficacy in prospective teachers, both academic learning as well as experiential learning are important.

Designing and securing teaching experiences that meet all four sources of personal information that contribute to self-efficacy is one way to maintain or further enhance prospective teachers' high self-efficacy in teaching. Planning for and securing these four sources of personal information into a quality student teaching program will promote better prepared teachers. Clinical models are now being explored with the aspiration of getting prospective teachers sooner in the classroom [28]. Earlier classroom exposure will provide a realistic experience where teaching skills can gain momentum. An authentic setting creates a learning environment that will promote opportunities for successful experiences including immediate feedback. According to Darling-Hammond [29], it is essential that prospective teachers have the opportunity to practice and develop their teaching skills in a safe and controlled environment under the direction and supervision of educational experts in schools where diverse learners are served effectively and good teaching is developed and modeled. She argues for literacy course work that uses pedagogies that link theory and practice and are tightly integrated with supervised clinical work.

This study revealed that content knowledge did not significantly predict self-efficacy nor did self-efficacy predict content knowledge. Having confidence in oneself as a teacher was formed early on for these prospective teachers even before entering into the literacy methods courses of the education program. Knowing that prospective teachers are already self-efficacious suggests that they most likely can persevere in the face of difficulties and have sufficient coping mechanisms to work through any disequilibrium they may experience [3]. Complex academic knowledge constructs necessary for teaching children how to read will be pursued with expectations of successful attainment. Finally, highly self-efficacious prospective teachers implies that prospective teachers are ready for subject-matter course work that is intensely integrated with clinical training where they can learn best by studying from educational experts while still performing, reflecting, watching, and talking to effective classroom teachers.

\section{REFERENCES}

[1] A. Bandura. Self-efficacy: Toward a unifying theory of behavioral change. Psychological Review, Vol.84, No.2, 191-215, 1977.

[2] G. V. Caprara, C. Barbaranelli, P. Steca, P. S. Malone. Teachers' self-efficacy beliefs as determinants of job satisfaction and students' academic achievement: A study at the school level. Journal of School Psychology, Vol.44, No.6, 473-490, 2006.
[3] C. E. Snow, P. Griffin, M. S. Burns. Knowledge to support the teaching of reading: Preparing teachers for a changing world. San Francisco, CA: Jossey-Bass. 2005.

[4] A. Bandura. Self-efficacy: The exercise of control. New York: Freeman, 1997.

[5] F. Pajares. Overview of social cognitive theory and of self-efficacy, 2002. Online available from http://www.emory .edu/EDUCATION/mfpeff.html

[6] R. M. Allinder. The relationship between efficacy and the instructional practices of special education teachers and consultants. Teacher Education and Special Education, Vol.17, No.2, 86-95, 1994.

[7] T. R. Guskey. Teacher efficacy, self-concept, and attitudes toward the implementation of instructional innovation. Teaching and Teacher Education, Vol.4, 63-69, 1988.

[8] M. Stein, M., M. Wang. Teacher development and school improvement: The process of teacher change. Teaching and Teacher Education, Vol.4, No.2, 171-187, 1988.

[9] D. Armor, P. Conroy-Oseguera, M. Cox, N. King, L. McDonnell, A. Pascal, et al. Analysis of the school preferred reading programs in selected Los Angeles minority schools. (Report No. R-2007-LAUSD). Santa Monica, CA: Rand Corporation. (ERIC Document Reproduction Service No. $130243), 1976$.

[10] S. Gibson, M. Dembo. Teacher efficacy: A construct validation. Journal of Educational Psychology, Vo.76, 569-582, 1984.

[11] P. T. Ashton, R. B. Webb, N. Doda. Study of teachers' sense of self-efficacy: Final report (Vol.1). Gainesville: University of Florida, 1983.

[12] P. T. Ashton, R. B. Web. Making a difference: Teachers' sense of efficacy and student achievement. New York: Longman, 1986.

[13] D. Britzman. Practice makes practice: A critical study of learning to teach. New York: State University of New York Press, 1991.

[14] J. Calderhead, M. Robson. Images of teaching: Student teachers" early conceptions of classroom practice. Teaching and Teacher Education, Vol.7, No.1, 1-8, 1991.

[15] K. M. Zeichner, B. R. Tabachnick. Are effects of university teacher education washed out by school experiences? Journal of Teacher Education, Vol.32, 7-11, 1981.

[16] J. Mulholland, J. Wallace. Teacher induction and elementary science teaching: Enhancing efficacy. Teaching and Teacher Education, Vol.17, 241-261, 2001.

[17] M. Tschannen-Moran, A. Woolfolk Hoy, W. K. Hoy. Teacher efficacy: Its meaning and measure. Review of Educational Research, Vol.68, 202-248, 1998.

[18] D. S. Strickland, C. Snow, P. Griffin, M. S. Burns, P. McNamara, P. Preparing our teachers: Opportunities for better reading instruction. Washington, DC: John Henry Press. 2002.

[19] R. C. Anderson, E. F. Hiebert, J. A. Scott, I. A. G. Wilkinson. Becoming a nation of readers: The report of the commission of reading. Washington, DC: The National Institute of Education, 1985. 
[20] R. F. Ferguson. Paying for public education: New evidence on how and why money matters. Harvard Journal of Legislation, Vol.282, 465-498, 1991.

[21] P. McCardle, V. Chhabra. The voice of evidence in reading research. Baltimore: Paul H. Brookes, 2004.

[22] J. Mosenthal, M. Lipson, S. Torncello, B. Russ, J. Mekkelsen. Contexts and practices of six schools successful in obtaining reading achievement. Elementary School Journal, Vol.104, No.5, 343-367, 2004.

[23] B. Rowan, R. Correnti, R. J. Miller, R.J. What large-scale, survey research tells us about teacher effects on student achievement: Insights from the Prospectus study of elementary schools. Teachers College Record, Vol.104, No.8, 1525-1567, 2002.

[24] W. L. Sanders, J. C. Rivers. Cumulative and residual effects of teachers on future student academic achievement. Knoxville: University of Tennessee Value-Added Research and Assessment Center, 1996.
[25] A. Bandura. Guide for constructing self-efficacy scales. Self-efficacy beliefs of adolescents, Vol.5, 307-337, 2006.

[26] Ecjprieto, Teacher Knowledge of Reading. ProProfs Quiz Maker, 2009. Online available from http://www.proprofs.co $\mathrm{m} /$ quiz-school/story.php?title=teacher-knowledge-reading

[27] A. E. Cunningham, J. Zibulsky, M. D. Callahan. Starting small: Building preschool teacher knowledge that supports early literacy development. Reading and Writing, Vol.22, 487-510, 2009

[28] K. Zeichner. Rethinking the connections between campus courses and field experiences in college-and university-based teacher education.Journal of teacher education, 61(1-2), 89-99, 2010.

[29] L. Darling-Hammond, L. Constructing 21st-century teacher education. Journal of teacher education, 57(3), 300-314, 2006. 